\title{
KESANTUNAN BERBAHASA MAHASISWA PRODI AGROTEKNOLOGI UPN VETERAN JAWA TIMUR UNTUK MENGUKUR EFEKTIVITAS MATA KULIAH BELA NEGARA
}

\section{THE POLITNESS LANGUAGE OF AGROTECHNOLOGY MAJOR STUDENTS IN UPN VETERAN EAST JAVA TO MEASURE THE EFFECTIVENESS IN DEFENDING COUNTRY COURSE}

\author{
Dewi Puspa Arum* \\ Agroteknologi, Universitas Pembangunan Nasional Veteran Jawa Timur, Indonesia \\ dewiarum.agrotek@upnjatim.ac.id \\ *penulis korespondensi
}

\begin{tabular}{ll}
\hline Info Artikel & ABSTRAK \\
\hline Sejarah artikel: & Penelitian ini bertujuan untuk mengukur efektivitas mata kuliah Bela \\
Diterima: & Negara terhadap kesantunan berbahasa mahasiswa kepada dosen sesuai \\
29 November 2019 & dengan teori kesantunan Leech. Terdapat perbedaan sikap dalam hal \\
Direvisi: & kesantunan berbahasa antara mahasiswa yang belum dan telah mempelajari \\
9 Desember 2019 & mata kuliah Bela Negara. Perbedaan sikap ini merupakan indikator yang \\
Disetujui: & menandakan bahwa mata kuliah Bela Negara terbukti berhasil dan efektif \\
15 Januari 2020 & dalam membentuk karakter mahasiswa UPN Veteran Jawa Timur. \\
& Penelitian ini mengkaji penggunaan maksim-maksim kesantunan berbahasa \\
Kata kunci: & pada tuturan tertulis menggunakan media komunikasi WA (whatsapp) \\
bela negara, & antara dosen dan mahasiswa di Prodi Agroteknologi, Fakultas Pertanian, \\
kesantunan berbahasa, & UPN Veteran Jawa Timur. Metode pengumpulan data berupa dokumentasi. \\
maksim percakapan & Metode analisis data yang digunakan adalah agih dengan teknik pilah dan \\
& $\begin{array}{l}\text { perluas. Metode pengujian kesahihan data menggunakan triangulasi sumber } \\
\text { data. Hasil penelitian menunjukkan adanya perbedaan kesantunan }\end{array}$ \\
& berbahasa antara mahasiswa yang telah menerima dan belum menerima \\
& mata kuliah Bela Negara. Mahasiswa yang telah menerima Mata Kuliah \\
Bela Negara lebih santun dalam berbahasa dan berkomunikasi \\
mengunakan media WA dibandingkan mahasiswa yang belum menerima
\end{tabular}

\begin{tabular}{|c|c|}
\hline Article Info & ABSTRACT \\
\hline $\begin{array}{l}\text { Article history: } \\
\text { Received: } \\
29 \text { November } 2019 \\
\text { Revised: } \\
9 \text { December } 2019 \\
\text { Accepted: } \\
15 \text { January } 2020 \\
\text { Keywords: } \\
\text { bela negara, politeness } \\
\text { in language, maxim of } \\
\text { conversation }\end{array}$ & $\begin{array}{l}\text { This study aims to measure the effectiveness of the Defending Country } \\
\text { course on the politeness of students' language to lecturers in accordance with } \\
\text { Leech politeness theory. There are differences in attitudes in terms of } \\
\text { politeness in language between students who have not and have studied the } \\
\text { Defending Country courses. This difference in attitude is an indicator that } \\
\text { indicates that the Bela Negara course has proven to be successful and } \\
\text { effective in shaping the character of UPN Veteran students in East Java. This } \\
\text { study examines the use of maxim politeness language in written speech } \\
\text { using WA (whatsapp) communication media between lecturers and students } \\
\text { at the Faculty of Agriculture, UPN Veteran East Java. The data collection } \\
\text { method is in the form of documentation. The data analysis method used is } \\
\text { divided into sort and expand techniques. The validity test method uses } \\
\text { triangulation of data sources. The results showed a difference in politeness } \\
\text { in language between students who had received and had not received the } \\
\text { Defending Country course. Students who have received Defending Country }\end{array}$ \\
\hline
\end{tabular}


courses are more polite in language and communication using WA media compared to students who have not received Defending Country courses.

\section{PENDAHULUAN}

Bahasa merupakan media untuk berkomunikasi. Dengan menggunakan bahasa, seseorang dapat mengungkapkan pemikirannya dan berinteraksi dengan orang lain. Secara ringkas, tujuan komunikasi dapat tercapai jika antarpenutur dapat saling memahami pesan yang disampaikan. Hal ini senada dengan tujuan komunikasi yang disampaikan oleh Hewitt (1981), yaitu tujuan komunikasi antara lain untuk mendalami atau mengajarkan sesuatu, mempengaruhi perilaku seseorang, mengungkapkan perasaan, menjelaskan perilaku sendiri atau perilaku orang lain, berhubungan dengan orang lain, menyelesaikan suatu permasalahan atau persoalan, mencapai suatu tujuan, dan menurunkan ketegangan, serta menyelesaikan konflik. Berkaitan dengan tujuan komunikasi tersebut, ucapan pikiran yang disampaikan kepada lawan tutur tidak pernah terlepas dari persoalan sopan santun (Nisja, 2009:478).

Bahasa menentukan peradaban suatu bangsa. Sebuah slogan yang sangat tepat untuk menggambarkan keterkaitan antara kesantunan, etika, dan tingkat peradaban suatu bangsa. Kesantunan berbahasa dan etika mahasiswa yang hidup di era disrupsi saat ini tentunya merupakan hal yang sangat penting dan menarik untuk dikaji. Perkembangan teknologi informasi dan komunikasi yang cukup pesat memberikan dampak yang cukup signifikan pada sikap, perilaku, dan etika mahasiswa. Kesantunan (politeness) merupakan bagian dari etika, adat, dan aturan yang berlaku di masyarakat. Kesantunan yang memiliki kaitan erat dengan etika dan disebut pula sebagai tatakrama. Hal ini senada dengan pendapat yang disampaikan oleh Sapir dan Whorf (dalam Wahab, 1995) yang menyatakan bahwa bahasa menentukan perilaku budaya manusia. Orang yang beretika dan santun dalam berkomunikasi akan menggunakan pilihan kata yang baik, ungkapan yang baik, struktur kalimat yang baik, dan intonasi yang tepat sesuai dengan lawan bicara yang dihadapi.

Mahasiswa sebagai Agent of Change, kalangan terdidik, dan termasuk kaum intelek, sudah seharusnya mampu menerapkan kesantunan berbahasa dan etika dalam kehidupan sehari-hari. UPN Veteran Jawa Timur adalah salah satu kampus negeri yang berkarakter bela negara. Sebagai mahasiswa yang menuntut ilmu di kampus berkarakter bela negara, sudah seharusnya Mahasiswa UPN Veteran Veteran Jawa Timur mampu menerapkan nilai-nilai bela negara dalam kehidupan sehari-hari. Bela negara merupakan motivasi, tekad, sikap, dan perilaku yang dijiwai cinta NKRI berlandaskan Pancasila dan UUD 1945 yang rela berkorban demi kelangsungan kehidupan berbangsa dan bernegara.

Sebagai kampus berkarakter bela negara, Mata kuliah Bela Negara merupakan salah satu mata kuliah wajib di UPN Veteran Jawa Timur. Mata kuliah Bela Negara menerapkan semua nilai-nilai bela negara dan hal ini 
ditunjang pula dengan kegiatan Outbound Bela Negara. Nilai-nilai bela negara antara lain, cinta tanah air, kesadaaran berbangsa dan bernegara, yakin dan hidup berlandaskan pancasila, rela berkorban, dan memiliki kemampuan awal bela negara. Mata kuliah Bela Negara diberikan secara serentak di semester ganjil, tepatnya pada semester tiga dan semester lima.

Permasalahan yang diangkat dalam penelitian ini adalah tentang efektifitas Mata Kuliah Bela Negara pada kesantunan berbahasa dan etika mahasiswa UPN Veteran Jawa Timur. Penelitian ini bertujuan untuk mengukur efektifitas Mata kuliah Bela Negara terhadap kesantunan berbahasa mahasiswa UPN Veteran Jawa Timur sesuai dengan teori kesantunan Leech.

Sudah seharusnya terdapat perbedaan sikap dalam hal kesantunan berbahasa dan etika antara mahasiswa semester I, II, dan IV yang belum mempelajari mata kuliah Bela Negara dibandingkan mahasiswa semester III, V, VI, VII, dan VIII yang telah mempelajari mata kuliah Bela Negara. Perbedaan sikap dalam hal kesantunan berbahasa dan etika ini merupakan indikator yang menandakan bahwa mata kuliah Bela Negara terbukti berhasil dan efektif dalam membentuk karakter mahasiswa UPN Veteran Jawa Timur.

Dapat pula terjadi kondisi yang tidak dikehendaki, misal mahasiswa yang tetap santun dalam berbahasa dan memiliki etika meskipun belum mendapatkan mata kuliah Bela Negara. Dapat pula terjadi kondisi mahasiswa yang kurang memiliki kesantunan berbahasa dan etika meskipun telah menempuh mata kuliah Bela Negara. Hal ini kembali pada sikap dasar yang dimiliki oleh masing-masing individu.
Kesantunan dapat diartikan sebagai kehalusan dan baik (budi bahasanya, tingkah lakunya) (KBBI, 1990). Kesantunan juga dapat diartikan sebagai cara berbahasa dengan tujuan mendekatkan jarak sosial antara penutur antarpenutur dengan tujuan. Konsep kesantunan berkaitan dengan dua aspek utama yaitu pada aspek bahasa dan perilaku seseorang. Hal ini senada dengan pernyataan yang menyatakan bahwa kesantunan adalah sebuah istilah yang berkaitan dengan kesopanan, rasa hormat, sikap yang baik atau perilaku pantas. Dalam kehidupan sehari-hari, keterkaitan kesantunan dengan perilaku yang pantas mengisyaratkan bahwa kesantunan bukan hanya berkaitan dengan bahasa, melainkan juga dengan perilaku nonverbal. Kesantunan menghubungkan bahasa dengan berbagai aspek dalam struktir sosial sebagaimana halnya dengan aturan perilaku atau etika. Sopan santun dalam bentuk tuturan atau kesantunan berbahasa setidaknya bukan sematamata motivasi utama bagi penutur untuk berbicara, melainkan juga merupakan faktor pengatur yang menjaga agar percakapan berlangsung dengan benar, menyenangkan, dan tidak sia-sia (Gunawan, 2013).

Kesantunan bersifat relatif di dalam masyarakat. Ujaran tertentu bisa dikatakan santun di dalam suatu kelompok masyarakat tertentu, akan tetapi di kelompok masyarakat lain bisa dikatakan tidak santun. Menurut Zamzani, dkk. (2010:2) kesantunan (politeness) merupakan perilaku yang diekspresikan dengan cara yang baik atau beretika. Kesantunan merupakan fenomena kultural, sehingga apa yang dianggap santun oleh suatu kultur mungkin tidak demikian halnya dengan kultur yang lain. Tujuan kesantunan, 
termasuk kesantunan berbahasa, adalah membuat suasana berinteraksi menyenangkan, tidak mengancam muka dan efektif.

$$
\text { Zamzani, dkk. (2010:20) }
$$

merumuskan beberapa ciri tuturan yang baik berdasarkan prinsip kesantunan Leech, yakni sebagai berikut: 1) tuturan yang menguntungkan orang lain, 2) tuturan yang meminimalkan keuntungan bagi diri sendiri, 3) tuturan yang menghormati orang lain, 4) tuturan yang merendahkan hati sendiri, 5) tuturan yang memaksimalkan kecocokan tuturan dengan orang lain, 6) tuturan yang memaksimalkan rasa simpati pada orang lain.

Dalam sebuah tuturan juga diperlukan indikator-indikator untuk mengukur kesantunan sebuah tuturan, khususnya diksi. Pranowo (2009: 104) memberikan saran agar tuturan dapat mencerminkan kesantunan kepada orang lain, yakni sebagai berikut: 1) gunakan kata "tolong" untuk meminta bantuan pada orang lain, 2) gunakan kata "maaf" untuk tuturan yang diperkirakan akan menyinggung perasaan lain, 3) gunakan kata "terima kasih" sebagai penghormatan atas kebaikan orang lain, 4) gunakan kata "berkenan" untuk meminta kesediaan orang lain melakukan sesuatu, 5) gunakan kata "beliau" untuk menyebut orang ketiga yang dihormati, dan 6) gunakan kata "bapak/ibu" untuk menyapa orang ketiga.

Implementasi indikator kesantunan dalam berkomunikasi digunakan agar kegiatan berbahasa dapat mencapai tujuan. Berdasarkan pendapat beberapa ahli, Pranowo (2009: 110) menguraikan hal-hal yang perlu diperhatikan agar komunikasi dapat berhasil, yakni sebagai berikut: 1) perhatikan situasinya, 2) perhatikan mitra tuturnya, 3) perhatikan pesan yang disampaikan, 4) perhatikan tujuan yang hendak dicapai, 5) perhatikan cara menyampaikan, 6) perhatikan norma yang berlaku dalam masyarakat, 7) perhatikan ragam bahasa yang digunakan, 8) perhatikan relevansi tuturannya, 9) jagalah martabat atau perasaan mitra tutur, 10) hindari hal-hal yang kurang baik bagi mitra tutur (konfrontasi dengan mitra tutur), 11) hindari pujian untuk diri sendiri, 12) berikan keuntungan pada mitra tutur. 13) berikan pujian pada mitra tutur, 14) ungkapkan rasa simpati pada mitra tutur. 15) ungkapkan hal-hal yang membuat mitra tutur menjadi senang, dan 16) buatlah kesepahaman dengan mitra tutur.

Leech (1993:124) menyatakan bahwa prinsip kesantunan merupakan prinsip yang harus menjaga keseimbangan sosial dan keramahan hubungan, karena hanya dengan hubungan-hubungan yang demikian kita dapat mengharapkan bahwa peserta yang lain akan bekerja sama. Dengan adanya pematuhan terhadap prinsip kesantunan ini, diharapkan pembicaraan atau hubungan seseorang dengan orang lain akan lebih bisa berjalan dengan lancar tanpa ada pihak yang merasa tersinggung atau dirugikan. Prinsip kesantunan merupakan sebuah prinsip percakapan yang harus dipatuhi oleh peserta tuturnya. Jika para penuturnya dapat mematuhi prinsip kesantunan ketika bertutur, mereka akan dapat saling menghormati dan menghargai dalam bertutur. Jika mereka sudah dapat saling menghargai dan santun dalam bertutur, akan tercipta sebuah kerja sama dalam bertutur.

Dalam berkomunikasi, di samping menerapkan prinsip kerja sama (cooperative principle) dengan keempat maksim (aturan) 
percakupannya, yaitu maksim kuantitas, maksim kualitas, maksim relevansi, dan maksim cara; juga menerapkan prinsip kesopanan dengan keenam maksimnay, yaitu (1) maksim kebijakan yang mengutamakan kearifan bahasa, (2) maksim penerimaan yang menguatamakan keuntungan untuk orang lain dan kerugian untuk diri sendiri, (3) maksim kemurahan yang mengutamakan kesalutan/rasa hormat pada orang lain dan rasa kurang hormat pada diri sendiri, (4) maksim kerendahan hati yang mengutamakan pujian pada orang lain dan rasa rendah hati pada diri sendiri, (5) maksim kecocokan yang mengutamakan kecocokan pada orang lain, dan (6) maksim kesimpatisan yang mengutakan rasa simpati pada orang lain. Dengan menerapkan prinsip kesopanan ini, orang todak lagi menggunakan ungkapan-ungkapan yag merendahkan orang lain sehingga komunikasi akan berjalan dalam situasi yang kondusif.

Bela Negara adalah sebuah konsep yang disusun oleh perangkat perundangan dan petinggi suatu negara tentang patriotisme seseorang, suatu kelompok atau seluruh komponen dari suatu negara dalam kepentingan mempertahankan eksistensi negara tersebut. Setiap warga negara memiliki kewajiban yang sama dalam masalah pembelaan negara. Hal tersebut merupakan wujud kecintaan seorang warga negara pada tanah air yang sudah memberikan kehidupan padanya. Hal ini terjadi sejak seseorang lahir, tumbuh dewasa serta dalam upayanya mencari penghidupan.

Nilai-nilai bela negara yang diajarkan ke mahasiswa antara lain, (1) cinta tanah air, (2) sadar akan berbangsa dan bernegara, (3) yakin kepada Pancasila sebagai ideologi negara, (4) rela berkorban untuk bangsa dan negara, (5) memiliki kemampuan awal bela negara secara psikis dan fisik. (Abidin, 2014:3).

\section{METODE}

Metode penelitian yang digunakan dipilah dalam tiga bagian yaitu dalam melaksanakan (a) penjaringan data, (b) analisis data, dan (c) penyajian hasil. Untuk mendapatkan data digunakan teknik penjaringan data melalui data tertulis, atau teknik dokumentasi, dalam hal ini data percakapan melalui media komunikasi WA (whatsapp). Data terkumpul kemudian masuk pada tahap analisis data.

Analisis data digunakan metode agih, yang dibantu dengan beberapa teknik analisis, antara lain teknik pilah dan teknik perluas. Teknik pilah dimanfaatkan untuk membagi atau mengelompokkan jawaban-jawaban sejenis terkait kesantunan berbahasa. Teknik perluas dimanfaatkan untuk menjelaskan makna dan maksud ujaran dalam kaitannya dengan kesantunan berbahasa. Hasil analisis disajikan dalam bentuk deskripsi kualitatif dengan metode informal (Sudaryanto, 1993:145), yaitu perumusan dengan kata-kata biasa.

Lokasi penelitian ini adalah di Prodi Agroteknologi, UPN Veteran Jawa Timur. Objek penelitian ini adalah mahasiswa semester I dan III, serta dosen mata kuliah Bela Negara dan Pancasila yang telah ditentukan sebelumnya. Subjek dalam penelitian ini adalah peneliti yang berperan sebagai penganalisis dalam proses pemilahan data, pembahasan, dan penarikan simpulan.

Tahapan-tahapan dalam penelitian ini antara lain pemilihan sumber data akan didokumentasikan 
percakapan WA-nya, baik dari mahasiswa maupun dosen. Selanjutnya, data yang terkumpul akan dipilah dan dikelompokkan berdasarkan rumusan masalah yang ada, yaitu tentang kesantunan berbahasa mahasiswa yang sesuai dengan maksim-maksim kesantunan berbahasa. Selanjutnya, data yang telah terkumpul akan dianalisis menggunakan agih untuk menentukan keefektifan pembelajaran mata kuliah Bela Negara pada kesantunan berbahasa mahasiswa Prodi Agroteknologi UPN Veteran Jawa Timur.

Analisis data dengan menggunakan teknik analisis interaktif menurut Miles dan Huberman yang terdiri atas tiga komponen penting, meliputi reduksi data, penyajian data, dan penarikan simpulan atau verifikasi (Miles \& Huberman, 1994:19). Teknik uji validitas data menggunakan triangulasi teori dan triangulasi sumber.

\section{HASIL DAN PEMBAHASAN Maksim kebijaksanaan}

Maksim kebijaksanaan memiliki kaidah memaksimalkan keuntungan bagi orang lain dan mengurangi keuntungan diri sendiri dalam kegiatan bertutur. Maksim kebijaksanaan mencerminkan kesantunan karena semakin panjang tuturan yang disampaikan menunjukkan keinginan yang besar untuk menghargai lawan bicara. Leech (1993:206) menggunakan istilah maksim kearifan.

Ditemukan data yang menunjukkan maksim ini, misalnya data (1) yang disampaikan oleh mahasiswa semester III ketika menanyakan tugas untuk pertemuan selanjutnya dengan mengawali percakapan menggunakan salam dan memperkenalkan diri meskipun dosen telah menyimpan nomor telepon mahasiswa tersebut.

(1) M: Assalamualaikum. Selamat siang, Pak. Nama Saya XX NPM XX dari Prodi Agroteknologi kelas B. Saya bermaksud menanyakan tugas yang Bapak berikan minggu lalu tentang Vlog Bela Negara. Apakah tugas tersebut juga diunggah ke youtube ataukah hanya diunggah ke instagram? Hal ini dikarenakan ketua kelas Agroteknologi E menyatakan demikian. Terima kasih atas jawaban Bapak dan mohon maaf sudah mengganggu. Wasslamualaikum wr.wb.

D: Iya, diupload ke youtube. (MKbj, III, BN, S)

Pada data (1) tuturan dimulai dengan salam dan perkenalan yang menyebutkan nama, nomor induk mahasiswa, prodi dan kelas. Selanjutnya penutur secara santun mengawali pertanyaan dengan informasi awal tentang tugas yang telah diberikan petutur pada pertemuan sebelumnya. Pertanyaan tersebut juga diawali dengan salam penutup, ucapan terima kasih dan permohonan maaf karena penutur merasa telah mengganggu waktu petutur. Setelah itu, petutur hanya menjawab pendek dengaan menyatakan pembenaran atas pertanyaan penutur bahwa tugas yang diberikan juga diunggah ke youtube. Dalam percakapan ini terdapat maksim kebijaksanaan yang menunjukkan bahwa petutur meminimalkan keuntungan bagi diri sendiri dan memaksimalkan keuntungan bagi petutur. Hal ini tampak dari jumlah kata penutur yang cukup banyak dan hanya dijawab singkat oleh petutur. 
Hal ini tampak berbeda jika dibandingkan dengan mahasiswa semester I yang belum menempuh mata kuliah Bela Negara. Mahasiswa cenderung tidak menggunakan maksim kebijaksanaan ketika berkomunikasi dengan dosen dalam percakapan WA, Misalnya tampak dalam tuturan berikut ini.

(1a) M: Pak, apakah tugas pancasila dikumpulkan besok? D: Iya, besok sebelum pukul 12.00 secara kolektif di ketua kelas Anda ya!

(MKbj, I, PC, KS)

Pada data (1a) tuturan dimulai tanpa memperkenalkan diri, tanpa salam, dan tanpa ucapan terima kasih ataupun permohonan maaf. Penutur secara singkat langsung menyakan masalah waktu pengumpulan tugas mata kuliah Pancasila yang telah diberikan sebelumnya. Hal ini menunjukkan bahwa penutur tidak menggunakan maksim kebijaksanaan dalam menyampaikan tuturannya. Sementara itu, petutur justru menunjukkan maksim kebijaksanaan dengan memberikan jawaban yang panjang lebar mengenai waktu pengumpulan tugas danteknis pengumpulan tugas yang ditanyakan oleh penutur.

Data (1) berbeda dengan data (1a) dalam penerapan maksim kebijaksanaan yang seharusnya diterapkan oleh penutur selaku mahasiswa dalam konteks percakapan ini. Penutur dalam data (1) merupakan mahasiswa semester III yang sedang menempuh mata kuliah Bela Negara. Konteks percakapan tersebut terjadi pada minggu ke-9 perkuliahan. Hal ini menunjukkan bahwa mahasiswa tersebut telah memiliki kesantunan dalam berkomunikasi dengan dosen. Sementara itu, data (1a) dituturkan oleh mahasiswa semester I yang belum menempuh mata kuliah bela negara. Petutur dalam data (1a) adalah dosen mata kuliah Pancasila yang juga mengampu mata kuliah Bela Negara sehingga dapat ditemukan data tuturan yang berbeda dalam hal kesantunan antara mahasiswa semester I dan semester III. Dapat dilihat dalam tuturan tersebut, penutur (1a) tidak menerapkan maksim kebijaksanaan dalam berkomunikasi dengan petutur. Hal ini menunjukkan bahwa penutur tersebut belum dapat dikatakan santun ketika berkomunikasi dengan petutur.

Berkaitan dengan nilai-nilai bela negara, maka data (1) mencerminkan butir ke-4 dari nilai-nilai bela negara, yakni rela berkorban untuk bangsa dan negara. Sementara itu, data (1a) tidak mencerminkan butir ke-4 dari nilainilai bela begara. Jadi, dapat dikatakan bahwa maksim kebijaksanaan berkaitan erat dengan nilai-nilai bela negara.

\section{Maksim kedermawanan}

Maksim kedermawanan memiliki kaidah untuk membuat keuntungan diri sendirisekecil mungkin dan membuat kerugian sendiri sebesar mungkin dalam sebuah percakapan (Leech, 1993:209). Maksim kesantunan ini bertujuan untuk menghormati lawan tutur. Penghormatan dalam ini dapat ditunjukkan dengan mengurangi keuntungan bagi diri sendiri agar orang lain mendapat keuntungan yang lebih besar.

Ditemukan data yang menunjukkan adanya maksim kedermawanan dalam percakapan antara mahasiswa semester III dengan dosen mata kuliah Bela Negara. Misalnya dalam data berikut ini. 
(2) M: Selamat Pagi, Bu. Saya XX dari kelas Agroteknologi bermaksud menanyakan apakah hari ini Ibu bisa ditemui? Dimana dan jam berapa? Saya bermaksud menanyakan presensi sebagai syarat mengikuti UTS.

D: Iya. Nanti pukul 10 pagi di ruangan saya ya.

M: Baik Bu. Terima kasih.

M: (Pukul 10.00) Bu, saya sudah di depan ruangan ibu. Mohon maaf apakah Ibu sudah bisa ditemui?

D: (pukul 11.00) Mohon maaf saya ada seminar di Giri Pasca.

$\mathrm{M}$ : Lalu bagaimana $\mathrm{Bu}$ ? Apakah saya harus menunggu disini ataukah saya harus ke Giri Pasca?

D: Anda ke Giri Pasca saja sekarang ya!

M: Baik $\mathrm{Bu}$, saya ke sana sekarang. Terima kasih.

(MKdm, III, BN, S)

Data tuturan (2) dimulai dengan salam dan perkenalan diri, lalu penutur melanjutkan dengan menanyakan apakah petutur dapat ditemui di kampus untuk menanyakan tentang jumlah kehadiran selama pertemuan 1-7 sebagai syarat mengikuti UTS. Kemudian dijawab oleh petutur bahwa petutur dapat ditemui pukul 10 di ruangan kerja petutur. Selanjutnya, pada pukul 10.00 , penutur telah tiba di ruangan petutur, tapi petutur mengikuti kegiatan di Giri Pasca, gedung Pascasarjana UPN Veteran Jawa Timur. Pada komunikasi tersebut, petutur membalas pesan sekitar pukul 11.00. Selanjutnya, penutur berusaha untuk menanyakan apa yang harus dilakukan. Apakah harus menunggu di ruangan petutur ataukah petutur dapat ditemui di Giri Pasca. Pada bagian ini terdapat maksim kedermawanan. Hal ini terjadi ketika penutur menawarkan alternatif lain atas kondisi yang ada. Penutur berusaha untuk meminimalisasi keuntungan dirinya sendiri dan memaksimalkan keuntungan bagi petutur.

Hal ini tampak berbeda jika dibandingkan dengan mahasiswa semester I yang belum menempuh mata kuliah Bela Negara. Mahasiswa cenderung tidak menggunakan maksim kedermawanan ketika berkomunikasi dengan dosen dalam percakapan WA, Misalnya tampak dalam tuturan berikut ini.

(2a) $\mathrm{M}: \mathrm{Bu}$, apakah Ibu bisa ditemui di kampus hari ini? Jam berapa, Bu? Saya mau minta tanda tangan.

D; Pukul 09.00 ya.

$\mathrm{M}: \mathrm{Ok}, \mathrm{Bu}$.

M: (Pukul 09.00) Bu, saya sudah di depan kantor Ibu, tapi kok Ibu tidak ada?

D: (Pukul 10.00) Maaf saya sedang di rektorat, ada sosialisasi untuk dosen. Nanti temui saya pukul $12.00 \mathrm{di}$ ruangan ya!

M: Yaaaa, saya sudah pulang bu. Maaf.

(MKdm, I, PC, KS)

Pada data (2a) tuturan diawali dengan pertanyaan penutur yang bermaksud untuk izin menemui petutur. Setelah dijawab oleh petutur, penutur tampak menyanggupi untuk bisa menemui petutur pada waktu yang dijanjikan. Setelah itu, pada pukul 09.00, penutur telah tiba di ruang petutur, tetapi pada saat tersebut petutur sedang mengikuti kegiatan sosialisasi. Setelah 1 jam kemudian, petutur baru 
membalas pesan WA penutur dan menyatakan bahwa penutur dapat menemui petutur di ruang kerja petutur pada pukul 12. Sementara itu, penutur telah meninggalkan kampus pada pukul 09.00 dikarenakan petutur terlambat membalas pesan WA penutur.

Data (2) berbeda dengan data (2a) dalam penerapan maksim kedermawanan yang seharusnya diterapkan oleh penutur selaku mahasiswa dalam konteks percakapan ini. Penutur dalam data (2) merupakan mahasiswa semester III yang sedang menempuh mata kuliah Bela Negara. Konteks percakapan tersebut terjadi pada minggu ke-7 perkuliahan. Hal ini menunjukkan bahwa mahasiswa tersebut telah memiliki kesantunan dalam berkomunikasi dengan dosen. Sementara itu, data (2a) dituturkan oleh mahasiswa semester I yang belum menempuh mata kuliah bela negara.

Dapat dilihat dalam tuturan tersebut, penutur (2) telah menerapkan maksim kedermawanan dalam berkomunikasi. Hal ini ditunjukkan dengan sikap petutur yang rela menunggu meskipun petutur belum membalas pesan WA sesuai dengan jam yang ditentukan sebelumnya. Selain itu, penutur juga meminimalkan keuntungan bagi dirinya sendiri dan memaksimalkan keuntungan bagi petutur dengan cara menemui petutur di luar tempat yang telah dijanjikan. Berbeda dengan data (2a), penutur tidak menerapkan maksim kedermawanan dalam berkomunikasi dengan petutur. Penutur justru meninggalkan lokasi ketika petutur terlambat membalas pesan WA penutur. Hal ini menunjukkan bahwa penutur tersebut belum dapat dikatakan santun ketika berkomunikasi dengan petutur.

Berkaitan dengan nilai-nilai bela negara, maka data (2) mencerminkan butir ke-4 dari nilai-nilai bela negara, yakni rela berkorban untuk bangsa dan negara dan butir ke- 5 bela negara, yakni memiliki kemampuan awal bela negara secara fisik dan psikis. Sementara itu, data (2a) tidak mencerminkan butir ke4 dan ke-5 dari nilai-nilai bela begara. Jadi, dapat dikatakan bahwa maksim kedermawanan berkaitan erat dengan nilai-nilai bela negara.

\section{Maksim Penghargaan}

Maksim pujian memiliki kaidah untuk memaksimalkan pujian dan penghargaan kepada orang lain dan meminimalkan cacian atau pelecehan kepada lawan tutur. Seseorang akan dianggap santun apabila dalam proses tuturan selalu berusaha memberikan dukungan dan penghargaan kepada lawan tutur. Maksim pujian merupakan maksim yang berusaha mengecam orang lain sesedikit mungkin dan memuji orang lain sebanyak mungkin (Leech, 1993:206-207).Dengan menerapkan maksim pujian dalam percakapan diharapkan terjalin komunikasi yang positif dan dapat saling menghargai.

Ditemukan data yang menunjukkan adanya maksim penghargaan dalam percakapan antara mahasiswa semester III dengan dosen mata kuliah Bela Negara. Misalnya dalam data berikut ini.

(3) M: Pak, terkait materi Bab 3 hari ini, apakah saya boleh meminta video film pendek tentang cinta tanah air yang bapak gunakan di kelas tadi?

D: Sudah saya kirim ke koordinator kelas ya.

M: Baik, Pak terima kasih atas videonya dan terima kasih atas perkuliahan yang luar biasa membangkitkan semangat 
kami dalam mencintai dan membela Indonesia.

D: Jangan hanya diucapkan, tapi dibuktikan juga ya Mas!

Semangat!

M: Siap, Pak!

(MPhg, III, BN, S)

Data tuturan (3) dimulai dengan permintaan penutur terhadap materi perkuliahan Bela Negara yang berupa video tentang cinta tanah air. Kemudian petutur menjawab bahwa video tersebut telah dikirimkan kepada koordinator kelas. Selanjutnya, penutur berterima kasih dan memberikan ucapan terima kasih dan penghargaan berupa pujian kepada petutur atas materi perkuliahan yang dapat menumbuhkan semangat untuk mencintai dan membela tanah air. Percakapan tersebut ditutup dengan pernyataan petutur yang menyatakan bahwa semangat cinta tanah air seharusnya dibuktikan melalui tindakan nyata, bukan hanya berupa ucapan saja. Dalam percakapan ini terdapat maksim penghargaan yang menunjukkan bahwa petutur memaksimalkan pujian dan penghargaan kepada orang lain dan meminimalkan cacian atau pelecehan kepada lawan tutur. Hal ini tampak dari ucapan terima kasih dan pujian yang disampaikan oleh penutur kepada lawan tutur.

Hal ini tampak tidak berbeda jika dibandingkan dengan mahasiswa semester I yang belum menempuh mata kuliah Bela Negara. Mahasiswa tetap dapat menerapkan maksim penghargaan ketika berkomunikasi dengan dosen dalam percakapan WA, Misalnya tampak dalam tuturan berikut ini.

(3a) $\mathrm{M}: \mathrm{Bu}$, apakah saya boleh meminta file powerpoint yang Ibu ajarkan tadi?
D: (mengirim dokumen). Ini ya mbak materi bab 7 .

$\mathrm{M}$ : Ok, Bu. Terima kasih.

(MPhg, III, PC, S)

Pada data (3a), tuturan dimulai
dengan menanyakan materi perkuliahan hari ini yang berupa file powerpoint. Penutur meminta kepada petutur untuk mengirimkan materi tersebut. Kemudian, petutur mengirimkan materi yang diminta dan menambahkan sedikit penjelasan bahwa materi tersebut merupakan materi bab 7. Selanjutnya, penutur mengucapkan terima kasih. Penutur yang merupakan mahasiswa semester I telah dapat menerapkan maksim penghargaan kepada petutur setelah mendapatkan apa yang diminta. Dalam percakapan ini terdapat maksim penghargaan yang menunjukkan bahwa petutur memaksimalkan pujian dan penghargaan kepada orang lain dan meminimalkan cacian atau pelecehan kepada lawan tutur. Hal ini tampak dari ucapan terima kasih yang disampaikan oleh penutur kepada petutur.

Berkaitan dengan nilai-nilai bela negara, maka data (3) mencerminkan butir ke-1 dari nilai-nilai bela negara, yakni cinta tanah air dan butir ke-2 bela negara, yakni sadar akan berbangsa dan bernegara. Sementara itu, data (3a) tidak jauh berbeda dengan data (3). Data (3a) mencerminkan butir ke-2 dari nilai-nilai bela begara, yakni sadar akan berbangsa dan bernegara. Jadi, dapat dikatakan bahwa maksim penghargaan berkaitan erat dengan nilai-nilai bela negara.

\section{Maksim Kesederhanaan}

Maksim kesederhanaan atau kerendahan hati memiliki kaidah untuk meminimalkan pujian kepada diri sendiri dan memaksimalkan 
ketidakhormatan kepada diri sendiri. Leech (1993:207) menjelaskan bahwa maksim ini diungkapkan dengan tuturan ekspresif dan asertif. Maksim kerendahan hati memiliki prinsip dasar maksim yaitu (a) pujilah diri sendiri sesedikit mungkin, (b) kecamlah diri sendiri sebanyak mungkin. Dengan menerapkan maksim kesederhanaan atau kerendahan hati, diharapkan komunikasi dapat berjalan baik dan menghindari kesan mengunggulkan diri sendiri.

Ditemukan data yang menunjukkan adanya maksim kesederhanaan dalam percakapan antara mahasiswa semester III dengan dosen mata kuliah Bela Negara. Misalnya dalam data berikut ini.

(4) M: Pak Mohon maaf saya terlambat mengikuti perkuliahan bapak dikarenakan masih belum selesai fotocopy.

(5) D: Iya, tidak apa-apa. Mas, saya lupa memberitau, tolong nanti kalau naik ke kelas ambilkan presensi kehadiran kelas XX di ruang TU ya. Nanti saya langsung ke kelas

M: Sudah saya ambilkan Pak. Ada di meja dosen.

D: Wah, luar biasa. Ketua kelas teladan ini. Padahal tadi saya lupa mau minta tolong.

M: Ah biasa saja Pak. Kebetulan tadi saya lewat TU dan saya ingat kalau biasanya Bapak langsung ke kelas karena ruang kantor Bapak di lantai 2.

D: Ok Mas. Terima kasih banyak ya.

M: Sama-sama Pak.

(MKsd, III, BN, S)
Pada data (4), tuturan diawali dengan permohonan maaf penutur yang terlambat menghadiri perkuliahan. Kemudian, petutur membalas dengan meminta tolong agar penutur bersedia mengambilkan presensi kehadiran di ruang tata usaha. Selanjutnya, penutur menjawab bahwa ia telah mengambilkan presensi tersebut dan diletakkan di meja dosen. Petutur yang merasa bahwa hal ini bukanlah sebuah kebetulan lantas memuji kepekaan penutur dengan mengatakan bahwa penutur adlaah seorang ketua kelas teladan. Sementara itu, penutur merespon dengan mengatakan hal tersebut adalah hal yang biasa saja karena telah menjadi kebiasaannya sebagai koordinator kelas. Dalam percakapan ini terdapat maksim kesederhanaan. Hal ini ditunjukkan oleh penutur yang merespon dengan meminimalkan pujian kepada diri sendiri dan memaksimalkan ketidakhormatan kepada diri sendiri.

Hal ini tampak tidak berbeda jika dibandingkan dengan mahasiswa semester I yang belum menempuh mata kuliah Bela Negara. Mahasiswa telah dapat menerapkan maksim kesederhanaan saat berkomunikasi, misalnya tampak dalam tuturan berikut ini.

(4a) M: Selamat siang, Bu. Mohon maaf tadi di kelas Ibu akan menanyakan apa terkait tugas kelompok bab 4?

D: Siang Mbak, saya mau bertanya apakah Anda masih menyimpan nilai kuis bab 4 yang saat itu diujikan secara berkelompok? Saya cari daftar nilai tersebut tidak ada di dokumen saya. Mungkin Anda punya salinannya? 
M: Ada bu, tunggu sebentar ya bu, saya kirim fotonya. (melampirkan foto daftar nilai)

D: Terima kasih banyak, Mbak XX. Anda berbakat menjadi sekretaris.

M: Hehe, cita-cita saya ingin jadi petani bu. Bukan sekretaris.

D: Amiiin. Semoga terkabul ya Mbak.

(MKsd, I, PC, S)

Data tuturan (4a) diawali dengan pertanyaan penutur tentang pesan yang disampaikan oleh petutur ketika mengikuti perkuliahan pada hari tersebut. Petutur menjawab bahwa ia memerlukan data nilai tugas kuis yang diujikan secara berkelompok untuk materi bab 4. Penutur menjawab bahwa ia menyalin dan menyimpan data nilai yang diumumkan secara lisan tersebut. Kemudian, petutur memuji bahwa penutur cocok menjadi sorang sekretaris suatu hari nanti. Selanjutnya, penutur justru menjawab bahwa ia bercita-cita menjadi seorang petani bukan sekretaris. Penutur juga tidak menanggapi pujian yang disampaikan oleh petutur. Dalam percakapan ini terdapat maksim kesederhanaan. Hal ini ditunjukkan oleh penutur yang merespon dengan meminimalkan pujian kepada diri sendiri dengan cara tidak menanggapi pujian yang diberikan oleh petutur dan memaksimalkan ketidakhormatan kepada diri sendiri dengan cara menyampaikan bahwa ia menginginkan profesi lain di luar profesi yang disampaikan oleh petutur.

Berkaitan dengan nilai-nilai bela negara, maka data (4) mencerminkan butir ke-4 dari nilai-nilai bela negara, yakni rela berkorban untuk bangsa dan negara, dan butir ke-5 dari nilai-nilai bela negara, yakni memiliki kemampuan awal bela negara secara fisik dan psikis. Sementara itu, data (4a) tidak jauh berbeda dengan data (4). Data (4a) mencerminkan butir ke-4 dari nilai-nilai bela negara, yakni rela berkorban untuk bangsa dan negara, dan butir ke-5 dari nilai-nilai bela negara, yakni memiliki kemampuan awal bela negara secara fisik dan psikis. Jadi, dapat dikatakan bahwa maksim kesederhanaan berkaitan erat dengan nilai-nilai bela negara.

\section{Maksim kesepakatan}

Maksim ini memiliki kaidah untuk memaksimalkan kesepakatan atau kesetujuan dengan orang lain dan meminimalkan ketidaksepakatan atau ketidaksetujuan dengan orang lain. Maksim kesepakatan atau maksim kecocokan menuntut para peserta pertuturan mengusahakan agar ketaksepakatan antara diri dengan lain terjadi sesedikit mungkin dan mengusahakan kesepakatan antara diri dengan lain terjadi sebanyak mungkin (Leech, 1993:207).

Ditemukan data yang menunjukkan adanya maksim kesepakatan dalam percakapan antara mahasiswa semester III dengan dosen mata kuliah Bela Negara. Misalnya dalam data berikut ini.

(5) M: Pak, apakah hari ini ada kuliah? Saya dan teman-teman sudah menunggu di ruangan 302.

D: Maaf saya sedang berhalangaan hadir karena ada pengabdian masyarakat ke Trenggalek.

M: Lalu, apakah ada tugas untuk hari ini Pak? 
D: Iya, lanjutkan diskusi kelompok pertemuan sebelumnya. Jangan lupa catat siapa saja yang bertanya.

M: Baik Pak. Akan saya sampaikan ke teman-teman.

(MKck, III, BN, S)

Dalam data tuturan (5) tersebut, percakapan diawali dengan pertanyaan penutur tentang kehadiran petutur untuk memberikan perkuliahan pada hari tersebut. Penutur menanyakan karena petutur belum tiba di kelas hingga 50 menit setelah perkuliahan dimulai. Petutur menjawab bahwa ia berhalangan hadir karena menjalankan tugas pengabdian masyarakat ke Trenggalek. Kemudian penutur kembali menanyakan apakah ada tugas untuk pertemuan di hari itu. Petutur menjawab agar melanjutkan diskusi kelompok seperti pertemuan sebelumnya. Dalam percakapan ini terdapat maksim kecocokan atau kesetujuan. Hal ini dapat dilihat dari reaksi penutur ketika petutur berhalangan hadir. Penutur menanyakan apakah petutur hadir pada perkuliahan di hari itu. Ketika petutur menjawab berhalangan hadir, secara spontan penutur kembali menanyakan apakah ada tugas atau tidak. Pada bagian ini terjadi maksim kecocokan antara penutur dan petutur, yakni memaksimalkan kecocokan atau kesetujuan dengan orang lain dan meminimalkan ketidakcocokan atau ketidaksetujuan dengan orang lain.

Hal ini tampak berbeda jika dibandingkan dengan mahasiswa semester I yang belum menempuh mata kuliah Bela Negara. Mahasiswa cenderung tidak menggunakan maksim kecocokan ketika berkomunikasi dengan dosen dalam percakapan WA, misalnya tampak dalam tuturan berikut ini.

(5a) M: Selamat siang, Bu. Saya XX dari kelas XX bermaksud menanyakan apakah benar tugas kelompok kelas kami harus dikumpulkan hari rabu depan bu?

D: Iya benar.

$\mathrm{M}$ : Maaf Bu, kalau tidak salah, kelas kami mendapatkan perpanjangan waktu 1 minggu untuk mengerjakan tugas tersebut karena materi yang ibu kirimkan baru kami terima kemarin.

D: Bukannya sudah saya kirim dari minggu lalu, Mas?

M: Mohon maaf bu, kemarin kami baru menerima dari koordinator kelas. Dan kata dia itu baru ibu kirim malam harinya. Jadi bagaimana bu?

(MKck, I, PC, KS)

Data tuturan (5a) diawali dengan pertanyaan penutur tentang waktu pengumpulan tugas yang telah diberikan oleh petutur. Petutur membenarkan informasi yang ditanyakan oleh penutur tersebut. Selanjutnya, penutur justru menyangkal bahwa batas waktu pengumpulan tugas tersebut bukanlah rabu minggu depan, melainkan 2 minggu kemudian dengan menyampaikan alasan bahwa petutur telat mengirimkan materi tugas tersebut. Pernyataan ini disangkal oleh petutur. Akhirnya penutur menjelaskan bahwa petutur dapat mengecek kebenaran informasi tersebut ke koordinator kelas. Dalam percakapan ini tidak terdapat maksim kecocokan karena apa yang disampaikan oleh penutur tidak cocok dengan apa yang 
disampaikan oleh petutur. Hal ini bertentangan dengan kaidah maksim kecocokan, yakni memaksimalkan kecocokan atau kesetujuan dengan orang lain dan meminimalkan ketidakcocokan atau ketidaksetujuan dengan orang lain.

Data (5) berbeda dengan data (5a) dalam penerapan maksim kecocokan yang seharusnya diterapkan oleh penutur selaku mahasiswa dalam konteks percakapan ini. Penutur dalam data (5) merupakan mahasiswa semester III yang sedang menempuh mata kuliah Bela Negara. Konteks percakapan tersebut terjadi pada minggu ke-6 perkuliahan. Hal ini menunjukkan bahwa mahasiswa tersebut telah memiliki kesantunan dalam berkomunikasi dengan dosen. Sementara itu, data (5a) dituturkan oleh mahasiswa semester I yang belum menempuh mata kuliah bela negara. Petutur dalam data (1a) adalah dosen mata kuliah Pancasila. Dapat dilihat dalam tuturan tersebut, penutur (5a) tidak menerapkan maksim kecocokan dalam berkomunikasi dengan petutur karena terdapat perbedaan informasi dari kondisi yang seharusnya. Namun, hal ini tidak lantas menunjukkan bahwa penutur tersebut tidak santun. Dapat dilihat dalam percakapan tersebut, penutur memiliki kesantunan ketika berkomunikasi dengan petutur, hanya saja tidak terdapat maksim kecocokan dalam komunikasi tersebut.

Berkaitan dengan nilai-nilai bela negara, maka data (5) mencerminkan butir ke-2 dari nilai-nilai bela negara, yakni sadar akan berbangsa dan bernegara dan butir ke-4 dari nilai-nilai bela negara, yakni rela berkorban untuk bangsa dan negara. Sementara itu, data (5a) justru mencerminkan butir ke-5 dari nilai-nilai bela negara, yakni memiliki kemampuan awal bela negara secara fisik dan psikis. Jadi, dapat dikatakan bahwa maksim kesepakatan berkaitan erat dengan nilai-nilai bela negara.

\section{Maksim simpati}

Maksim ini memiliki kaidah untuk memaksimalkan simpati kepada orang lain dan meminimalkan antipati kepada orang lain. Menurut Leech, (1993:206 - 207) prinsip dasar maksim simpati adalah (a) kurangilah rasa antipati antara diri dengan lain hingga sekecil mungkin, (b) tingkatkan rasa simpati sebanyakbanyaknya antara diri dan lain. Maksim simpati ini tidak hanya ditujukan bagi orang yang mengalami musibah, tetapi juga kepada orang yang mendapatkan keberuntungan.

Ditemukan data yang menunjukkan adanya maksim simpati dalam percakapan antara mahasiswa semester III dengan dosen mata kuliah Bela Negara. Misalnya dalam data berikut ini.

(6) M: Selamat pagi, Pak. Apakah pagi ini ada perkuliahan? Kami sudah menunggu di ruangan. Terima kasih.

D: Maaf hari ini saya tidak masuk. Sedang tidak enak badan. Tolong sampaikan ke teman-teman ya. Hari ini tidak ada kuliah.

M: Semoga lekas sembuh, Pak. Baik Pak, saya sampaikan ke teman-teman ya.

D: Terima kasih untuk perhatiannya.

(MKsm, III, BN, S)

Data tuturan (6) diawali dengan pertanyaan penutur mengenai kehadiran petutur untuk perkuliahan di hari tersebut. Petutur menjawab bahwa 
ia berhalangan hadir karena sedang tidak enak badan. Selanjutnya, penutur menjawab dengan mendoakan agar petutur lekas sembuh dan dijawab terima kasih oleh petutur. Pada bagian ini, terdapat maksim simpati. Hal ini ditunjukkan oleh reaksi penutur yang secara spontan mendoakan kesembuhan bagi petutur. Tuturan ini sesuai dengan kaidah maksim simpati, yakni memaksimalkan simpati kepada orang lain dan meminimalkan antipati kepada orang lain.

Hal ini tampak tidak berbeda jika dibandingkan dengan mahasiswa semester I yang belum menempuh mata kuliah Bela Negara. Mahasiswa telah dapat menerapkan maksim simpati ketika berkomunikasi dengan dosen mata kuliah Pancasila dalam percakapan WA, misalnya tampak dalam tuturan berikut ini.

(6a) M: Selamat siang, Bu. Apakah hari ini ada perkuliahan?

D: Hari ini saya menghadiri pengukuhan guru besar teman saya di XX. Tolong sampaikan agar teman-teman mengerjakan tugas bab 4 ya.

M: Selamat atas pengukuhan guru besar teman $\mathrm{Bu} \mathrm{XX}$. Semoga sukses. Baik bu, akan saya sampaikan ke temanteman untuk mengerjakan tugas bab 4 .

D: Ok. Terima kasih ya. (MKsm, I, PC, S)

Data tuturan (6a) diawali dengan pertanyaan penutur apakah petutur akan hadir untuk mengisi perkuliahan di hari tersebut. Petutur menjawab bahwa ia berhalangan hadir karena menghadiri acara pengukuhan guru besar temannya di XX. Selanjutnya, penutur mengucapkan selamat dan mendoakan semoga sukses dan dijawab dengan ucapan terima kasih oleh petutur. Pada percakapan ini terdapat maksim simpati. Hal ini ditunjukkan oleh ucapan selamat dan doa semoga sukses padahal penutur tidak mengenal guru besar yang dimaksud. Maksim simpati ini tidak hanya ditujukan bagi orang yang mengalami musibah, tetapi juga kepada orang yang mendapatkan keberuntungan.

Data (6) dan (6a) tidak jauh berbeda dalam hal respon petutur terhadap kondisi petutur. Yang membedakan hanyalah informasi yang disampaikan oleh petutur. Tuturan (6) berisi informasi yang berupa musibah dan tuturan (6a) berisi informasi yang berisi keberuntungan. Dapat dikatakan pada bagian ini, mahasiswa semester III dan semester I dapat menerapkan kaidah maksim simpati dengan baik dalam merespon informasi.

Berkaitan dengan nilai-nilai bela negara, maka data (6) dan (6a) mencerminkan butir ke-2 dari nilainilai bela negara, yakni sadar akan berbangsa dan bernegara, dan butir ke5 dari nilai-nilai bela negara, yakni memiliki kemampuan awal bela negara secara fisik dan psikis. Jadi, dapat dikatakan bahwa maksim simpati berkaitan erat dengan nilai-nilai bela negara.

\section{PENUTUP}

Pada penelitian ini didapatkan simpulan bahwa mahasiswa semester III yang telah menempuh mata kuliah Bela Negara telah lebih santun dalam berkomunikasi kepada dosen melalui pesan whatsapp (WA). Hal ini dibuktikan dengan digunakannya enam maksim kesantunan Leech yaitu (1) maksim kebijaksanaan, (2) maksim kedermawanan, (3) maksim penghargaan, (4) maksim 
kesederhanaan,

(5) maksim

kesepakatan, dan (6) maksim simpati. Sementara itu, mahasiswa semester I yang belum menempuh mata kuliah Bela Negara dapat dikatakan belum sepenuhnya santun karena tidak menerapkan semua maksim kesantunan Leech. Maksim kesantunan yang telah diterapkan dalam percakapan melalui WA dengan dosen, yaitu (1) maksim penghargaan, (2) maksim kesederhanaan, dan (3) maksim simpati. Maksim yang belum diterapkan dalam percakapan melalui WA dengan dosen, yaitu (1) maksim kebijaksanaan, (2) maksim kedermawanan, dan (3) maksim kesepakatan. Oleh karena itu, dapat disimpulkan bahwa nilai-nilai bela negara dalam mata kuliah Bela Negara terbukti efektif dalam membentuk kesantunan berbahasa mahasiswa Prodi Agroteknologi, UPN Veteran Jawa Timur

\section{DAFTAR PUSTAKA}

Abidin, Zainal dkk. (2014). Buku Ajar Pendidikan Bela Negara. Surabaya: UPN Veteran Jawa Timur.

Gunawan, Fahmi. (2013). Wujud Kesantunan Berbahasa Mahasiswa terhadap Dosen di STAIN Kendari: Kajian Sosiopragmatik. Arbitrer: Scientific Journal of Linguistic Society of Indonesia (1)1: 8-9. Padang: MLI Cabang Universitas Andalas dan Fakultas Ilmu Budaya Universitas Andalas Padang.

Hewitt. (1981). Komunikasi, www.scribd.com , 12 Oktober 2019, pkl. 14.27
KBBI. (2016). Kamus Besar Bahasa Indonesia (KBBI). [Online] Available at: http://kbbi.web.id/santun [Diakses 23 Oktober 2019].

Leech, Geoffrey. (1993). Prinsipprinsip Pragmatik. Jakarta : Penerbit Universitas Indonesia (UI-Press).

Miles, M.B. \& Huberman, A.M. (1994). Qualitative Data Analysis. London : Sage Publishers.

Nisja, Indriani. (2009). 'Kesantunan Berbahasa dalam Berdiskusi Mahasiswa Jurusan Bahasa Indonesia Semester III Tahun 2007-2008 Ummy Solok'. Dalam Jurnal Ilmiah Tambua, Vol. VIII, No. 3, SeptemberDesember.

Pranowo. (2009). Berbahasa secara Santun. Yogyakarta: Pustaka Pelajar.

Sudaryanto. (1993). Metode dan Aneka Teknik Analisis Bahasa Pengantar Wacana Wahana Kebudayaan Secara Linguistik. Yogyakarta: Duta Wacana University Press.

Wahab, Abdul. (1995). Isu Linguistik: Pengajaran Bahasa dan Sastra. Surabaya: Airlangga University Press.

Zamzani, dkk. (2010). Pengembangan Alat Ukur Kesantunan Bahasa Indonesia dalam Interaksi Sosial Bersemuka dan Non Bersemuka. Laporan Penelitian Hibah Bersaing (Tahun Kedua). Yogyakarta: Universitas Negeri Yogyakarta. 